UDC 378.147::811.111](497.11)

Ivana Trbojević Milošević

University of Belgrade, Serbia

\title{
LEARNING THROUGH CONTRASTING: STUDENTS' PROJECTS AT THE DEPARTMENT OF ENGLISH, FACULTY OF PHILOLOGY IN BELGRADE
}

\begin{abstract}
The 2006/2007 generation of students, the first one to have taken the reformed course of studies at the English Department, Faculty of Philology in Belgrade graduated in June 2010. They are also the first generation of students of contrastive and corpus linguistics course not to have written traditional seminar papers individually, but have engaged in team effort and research of certain linguistic topics relying on the methods of contrastive and corpus linguistics. In this paper, I shall present the principles behind the decision to introduce this change in the curriculum, the aims of the project work, the actual implementation of those aims and the results of the students' efforts.
\end{abstract}

Key words: Bologna Declaration, contrastive linguistics, corpus linguistics, reformed curriculum, students' mini-projects

1. Background: the problems. Since 1929, when the English Department at Belgrade University was founded, the curriculum has undergone fourteen, more or less substantial reforms. The last one that followed in the wake of Serbia's official adoption of the Bologna Declaration principles (in September 2003) and the new High Education Law (July 2005), was long called for, although it definitely ran a risk of being too challenging. Certainly, it could have been carried out by formally introducing and adopting the European Credit Transfer System (ECTS) and by physically dividing the 
existing syllabi into a number of one-semester courses, which might have happened elsewhere. However, at the English Department of the Faculty of Philology in Belgrade, the requirement that was formally imposed by the state education policy and laws was felt and seen as a welcome chance to reassess and re-evaluate the existing curriculum - to carry out, in a way, a SWOT analysis and introduce changes in the curriculum with the objective to offer a modern, flexible and relevant model of academic studies. Although there had been attempts at modernizing the assessment system before , such as the introduction of 'counting-towards-the-exam' colloquiums at all fours years of study, we still lacked a supportive reference frame that could only be provided by the state (Trbojević, Rasulić and Jovanović: 2008).

The problems we were confronted with and that we felt needed addressing on a structural level were numerous. The last curricular reform had been carried out in the second half of eighties and though it had a favourable structure, its potential had never been utilized to the full: for example, the subjects indexed as special courses left plenty of room for the introduction of flexible, elective courses, but somehow that concept had not been exploited. On the other hand, the amount of content in the existing courses kept growing over the years/decades, and while that was a natural consequence of the scientific and academic disciplines' growth, it nevertheless aggravated students' workload. In some courses the amount of material to be covered became rather insurmountable, which resulted in ever worsening quality of student performance and output, leading to a formation of 'bottle-necks' in the exams.

Apart from the academic side of the problem, there also loomed the practical one: did the content of our academic courses and their structure actually prepare the students for the market challenges that awaited them after graduation? How realistic was it to expect that they meet the competitive market requirements and demands? The statistics were quite disheartening: in 2003, the official data showed that over 40\% of English teachers in elementary schools did not have the necessary qualifications, which meant that our graduates did not go to teaching jobs, but rather to more attractive jobs in trade and commerce, marketing, media, diplomacy, etc. So, without forgetting the importance of those subjects that provided pre-service training for our students, we had to balance it with more training in translation and interpreting skills, communications, specific purposes, cultural studies, etc. 
Ivana Trbojević Milošević, Learning through contrasting: students' projects ...

2. How it all came together. The curricular reform whose implementation started in 2006/2007 was described in detail in Rasulić \& Trbojević 2007. At this point, an example of how a particular course was treated and adapted to answer the requirements of the new curriculum will be given. The course in question is the Contrastive Analysis of English and Serbian which has, in continuo, been taught at the Department for thirty years (since 1979/1980). The aim of the course has been to introduce the students to the principles of language comparison within a synchronic frame in order to draw the similarities and differences between them. The practical aim was to develop awareness of differences necessary both for teaching, curriculum design, test design, etc., and translation practice. At least declaratively, one of the 'high-level' aims was to help students develop cross-cultural competences, understood as a set of cognitive, behavioural and affective components enabling them to get around successfully in intercultural settings.

In order to achieve all that, the students were first given the theoretical input in Contrastive Linguistics/Analysis, then they were presented with descriptions of both English and Serbian, and in their practical classes they did a thorough micro-linguistic analysis of chosen corpus of parallel examples in English and Serbian. Actually, the micro-linguistic analysis of decontextualized language material turned out to be the bottom line of the course. As said above, the course had been developed over almost 30 years, and its content had become huge. Eventually, it was clear that 15 weeks per semester and 4 periods per week were not enough, and the students needed up to intimidating 450-500 hours to prepare for the exam.

When such results were viewed in the context of other subjects, i.e. those dealing with the levels of linguistic analysis and the contemporary language courses, it became clear that our students' competences still remained at rather 'lifeless level', and it was not what we wanted to see as the 'end product' of the four-year study cycle.

As for the massive Contrastive Analysis Course, we decided to break it into three courses: Descriptive grammar 1, Descriptive grammar 2, and Contrastive linguistics with the Introduction to Corpus linguistics; given the fact that language description was a prerequisite for contrasting, we introduced two courses in Descriptive Grammar in the first and the second years of study. The first-year course covers the description of the Noun Phrase in English, whereas the second year course deals with the description of the Verb Phrase. In the first year students also have a mandatory course 
in Phonology and Phonetics, in the second year they get acquainted with English Morphology and in the third year they have a mandatory course in English Syntax.

By the time they reach their fourth year of studies, our students have already gone through a high-level integrated skills training in their Contemporary English courses, which also means elaborately graded procedures aimed at developing both speaking and writing skills. In the fourth year, choices get ampler for the students: depending on their affinities, they take up elective courses from four different modules: linguistic, applied linguistic, literature and cultural studies.

The entire setting at that point provides an environment favourable for introducing the third 'derivative' of the former CA course: the Contrastive Linguistics with an Introduction to Corpus Linguistics. The aims of the course apparently remained the same: to raise future language specialists' awareness of possible issues, problems and difficulties which may arise in language contacts due to the similarities, contrasts and differences between English and Serbian at different levels, including pragmatic and cultural; to equip the future language specialists with necessary academic, methodological and technical knowledge and skills that would allow them to carry out basic research.

The course lasts two semesters (60 hours of lectures and 60 hours of interactive practical classes). The first semester introduces students to basic theoretical concepts underlying contrastive analysis (such as comparability, correspondence, equivalence and translation equivalence, tertium comparationis, language universals etc.); the practical classes are mostly used for discussion of recommended literature and exemplification of certain analytical procedures in contrasting. After the first semester, the students take a mid-year colloquium. In the second semester, they get acquainted with the basic notions and principles of corpus linguistics (types of corpora, representativeness, principles of compiling, concordancing, tagging, etc.). Also, certain language segments are chosen for description and contrasting. In practical classes, students get acquainted with some commercially available corpora (such as the British National Corpus) and practise basic searches and analytic procedures on the chosen language segment. At the end of the second semester, they take end-of-the-year colloquium.

However, what represents a real innovation in this course and actually the rounding-up of a number of courses described and mentioned above is 
Ivana Trbojević Milošević, Learning through contrasting: students' projects ...

the project work which students are required to carry out, write a paper on and report about at the end of the school year (during the last two weeks of May). The Project Themes are distributed at the beginning of the second semester and students are given a couple of weeks' time to think, choose and get organized into teams of four. Depending on the theme, they are either required to compile their own corpora of examples for analysis, or they use the BNC.

For the purposes of illustration, here are the Project Themes for the year $2009 / 2010^{1}$ :

1. Syntactic Characteristics of Headlines in English and Serbian Daily Papers

2. The Present Simple Tense and the Present Progressive in English and Their Equivalent Forms in Serbian (Quality Weeklies Corpus)

3. The Use of Passive in English and Serbian Legal Texts

4. Light Verb Constructions in English and Serbian Legal Texts

5. Modals in English and Serbian Daily Press

6. Epistemic Modal Meanings in Written Political Discourse in English and Serbian

7. Deontic Modal Meanings in English and Serbian ( Women Magazines Corpus)

8. Gender of Animation in English Prose and Poetry : Translation Problems

9. Compounding in A. Roy's The God of Small Things and the Equivalent Forms in Its Serbian Translation

10. Types of Errors in the Translation of Harry Potter into Serbian

The students started working on their Projects the beginning of March. Throughout the process, they regularly came for consultations once a week, when they reported on their progress, asked for feedback and guidance. At the very beginning, each team was given a prepared minimal list of recommended reading, and they were also encouraged to do research for additional reading themselves. As they progressed, they also sent in their drafts through e-mail and got written feedback. Once the final draft was approved, they prepared it as a final paper (30-50 pages) which they handed in two days before the presentation in class. Each team

\footnotetext{
${ }^{1}$ Most of the Project Themes were based on the language segments that had previously been discussed and analyzed in class.
} 
was allotted 20 minutes for presentation and 10 minutes for discussion ${ }^{2}$. All students/teams were assessed and graded on both components of the Project: the written paper and presentation skills.

3. One thing leads to another. The idea behind the Students' Projects was to streamline their studies in the final year towards development of cross-cultural competences in the environment that in their chosen professions (whether they become teachers, interpreters, translators, media people or diplomats) would inevitably be intercultural ${ }^{3}$. In line with that, the students were actually given the power and responsibility of (almost) independent contrastive research with multiple aims:

1) consolidate and use knowledge and skills acquired in the previous academic courses, such as morphology, syntax, descriptive grammar, semantics, knowledge about Anglo-Saxon literature and cultures;

2) work towards their own discovery of those aspects of AngloAmerican cultures which are not overt and immediate, such as pragmatic patterns and subtleties;

3) work towards acquiring and developing academic skills such as analytical and reasoning skills, inferencing and summarizing.

4. Benefits and challenges. The benefits, according to the results we got at the end of the school year, were many: in view of 1 ), the students had to go back to what they learnt in the Descriptive Grammar Courses in the first two years of their studies ${ }^{4}$; they also had to activate their knowledge of various forms of syntactic analysis (Fig.1) and morphology (Fig.2)

2 The students already had experience with oral presentations, which are mandatory part of the Contemporary English courses and are amply used in literature and cultural studies courses.

3 'Intercultural' meaning not only multilingual, national or ethnic, but also in the sense in which it refers to different cultures within one language (i.e. academic culture, youth culture, professional culture, company culture etc.)

4 As one of the student's put it in her written comment of the course: 'It suddenly got a completely new sense, all that trouble with grammar.' 


\section{Verbal headlines}

- Finite verb phrases

The battle for libel reform has only begun (The Guardian 02 Apr, 2010)

- Non-finite verb phrases

Getting Out (The NY Times 28 Apr, 2010)

a Headlines with auxiliary omitted

Polish President Killed in Plane Crash in Russia (The NY Times 10 Apr, 2010)

a Complementation

Failure Is Not an Option (The NY Times 28 Apr, 2010)

n Subject adverbial headlines

Uncertainty ahead of today's inflation figures (The Guardian 23 Mar, 2010)

Fig. 1 A slide from a presentation on Project Theme 1.

\begin{tabular}{lll}
\hline schoolteacher-shaped & $\rightarrow$ & u obliku učiteljice \\
house-shaped & $\rightarrow$ & u obliku kuće \\
a frog-shaped & $\rightarrow$ & u obliku žabe \\
squashed frog-shaped & $\rightarrow$ & u obliku pregažene žabe \\
squashed crow-shaped & $\rightarrow$ & u obliku pregažene vrane \\
chef-shaped & $\rightarrow$ & u obliku kuvarske kape \\
black cat-shaped holes in the & $\rightarrow$ & crne rupe u Vasioni u obliku \\
Universe & & crne mačke \\
finger-coloured & $\rightarrow$ & boje prstiju \\
tea-coloured puddles & $\rightarrow$ & barice boje čaja \\
honey-coloured & $\rightarrow$ & boje meda \\
beach-coloured & $\rightarrow$ & boje peska \\
cabbage-green & $\rightarrow$ & zelen kao kupus \\
vinegar-hearted & srca kiselog kao sirće \\
snot-coloured & $\rightarrow$ & sivkast kao slina \\
lightening-quick & $\rightarrow$ & munjeviti \\
child-sized & $\rightarrow$ & dečiji \\
pus-filled & & gnojavi \\
soap-bubbled & $\rightarrow$ & sapunjava \\
nylon lace-curtained doorway & $\rightarrow$ & čipkane sintetičke zavese \\
ivory-handled & $\rightarrow$ & sa drškom od slonovače \\
serpent-headed & sa zmijskim glavama \\
fountain-haired & $\rightarrow$ & s palmicom na glavi \\
lemon-flavoured & $\rightarrow$ & sa ukusom limuna \\
\hline & $\rightarrow$ & \\
& & \\
\hline
\end{tabular}

Fig. 2 A slide from a presentation on Project Theme 9 
Some of the Project Themes led our students to recognize the importance of integrating knowledge about different disciplines, and their research had to be done literally across the curriculum. The students who researched the Project Theme 3, The Gender of Animation on English Prose and Poetry: Translation Problems threaded their way through and across linguistics, literature and translation theory (Fig.3)

\section{Perconiffeation in Bnglich Literature (Prose) \\ D.F. Lawrence}

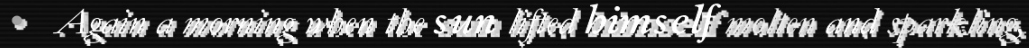

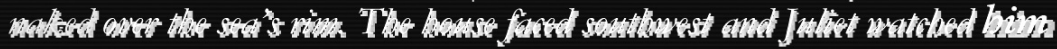

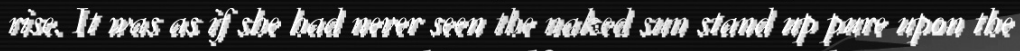

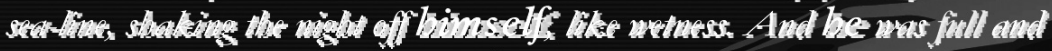

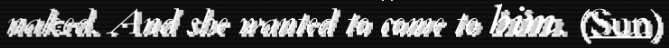

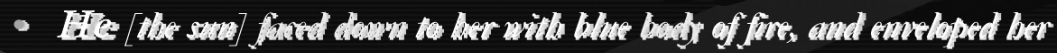

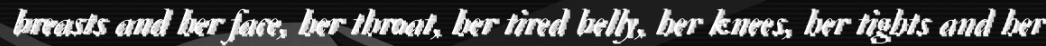
forts. (Sun)

Fig. 3 A slide from a presentation on Project Theme 8.

In terms of putting theoretical knowledge to practical use, the students had a chance to develop technical skills such as language sampling and corpus compiling, contrasting of relatively large corpora of examples (Fig.4); they were also required to exemplify and interpret, as well as to synthesize and present results as quantitative data (Fig.5) followed by qualitative interpretations (Fig.6). 


\section{- CORPUS}

- 500 English headlines and $\mathbf{5 0 0}$ Serbian headlines

a Relies on the information obtained from the internet

- Covers a brief period of time:

- Serbian headlines: February 15 - May 20, 2010

- English Headlines: March 23 - May 15, 2010

- Serbian Daily Papers: Blic (55), Press(120), Политика(90), Вечерње новости (105), 24sata(30)

- English Daily Papers: The Telegraph (90), The Guardian (85), The Independent (62), The Morning Star (60), The Daily Express (3), The New York Times (200)

Fig. 4 A slide from a presentation on Project Theme 1.

Another benefit lies in the fact that the students had to resort to all the writing skills they had developed up to that point and focus on developing academic writing skills in particular: they had to recognize the specificity of academic style (register), they had to show an ability to define and outline the scope and parameters of their research ; they were expected to be able to clearly set their objectives, and break the research and writing processes into stages, which required not only good organization in thinking all the way through the processes (Fig.7) but also called for team organization skills, building and maintaining group dynamics, distributing workload between the team members and working on interpersonal culture and team ethos.

Another important benefit drawn from the project work is that the students managed to put contrastive analysis in an adequate perspective: for years, the students somehow maintained the idea that contrastive analysis is a micro-linguistic discipline, instead of seeing it as a powerful methodological principle applicable at any level of micro/macro analysis. The teams who investigated pragmatic issues on the press/media corpus found their results revealing of certain aspects of both Anglo and Serbian 
cultures of which they have not been aware before, such as the pragmatic strength and pervasiveness of deontic modality in magazines for women.

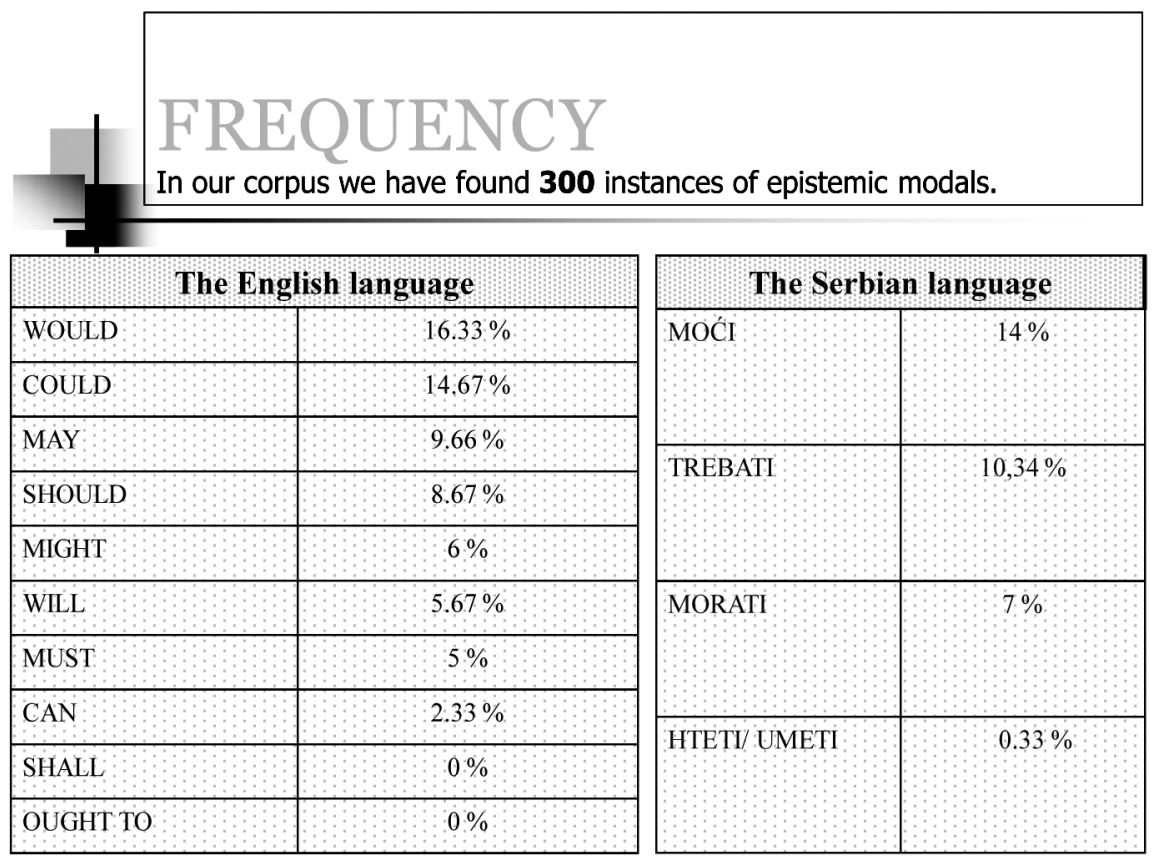

Fig. 5 A slide from a presentation on Project Theme 6.

What most of the students pointed as the greatest benefit of all, was that they had a chance to tackle real language as it is used in real life, which focused their interest on the issues of language usage and functional diversity. 


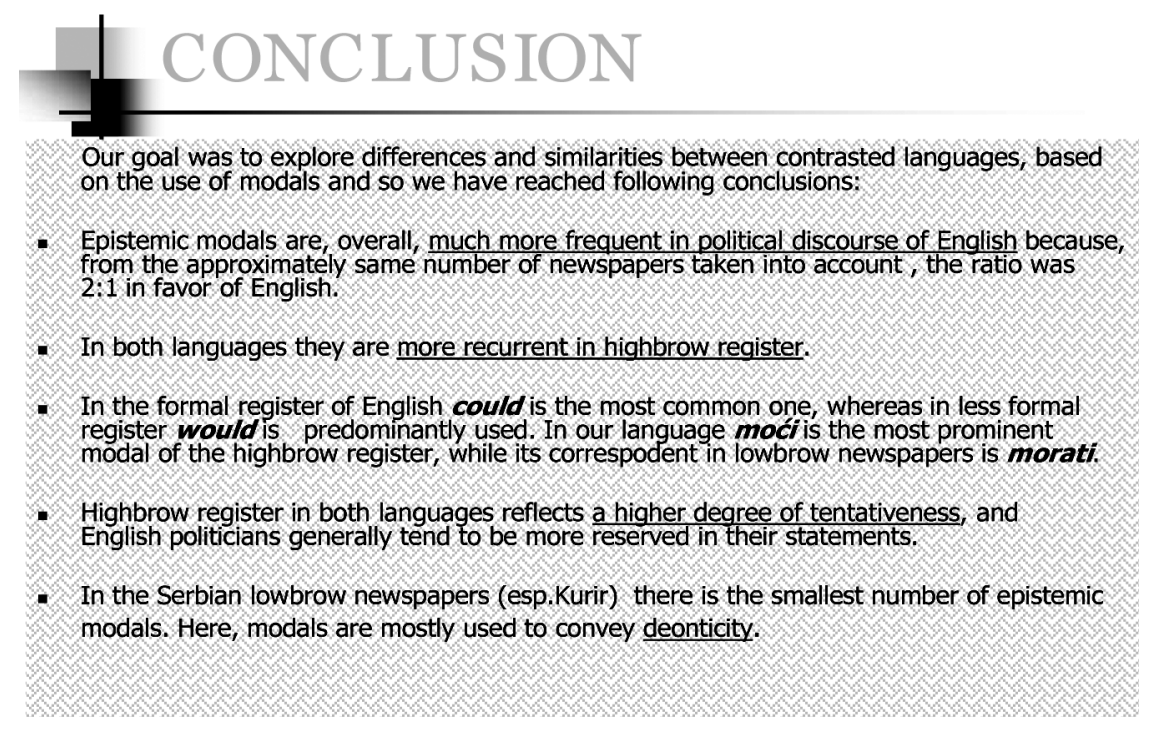

Fig. 6 A slide from a presentation on Project Theme 10.

Challenges, of course, were and are many: team work, although it has a number of advantages, certainly has its drawbacks when it comes to assessment - since the paper mark is 'shared' by all members of the team, and even in best will one can hardly say that all students take exactly the same credit for the success of the paper. However, I am convinced that the benefits, those listed above as well as those of psychological nature surpass this disadvantage.

Teacher workload and responsibility are immense: the implementation and monitoring of students' projects requires meticulous preparation-starting with the choice of project themes, over the preparation of recommended reading for the teams, careful preparation and planning for consultations, all the way to reading students papers and providing adequate feedback to help them edit their work. However, the reward is also great: the quality of the work they produce at the end of the process, their feeling of achievement and satisfaction with their accomplishment are certainly hard to top. 


\section{References}

Katz, A. (2008). Changing the culture of assessment: Redefining proficiency. In: ELLSSAC Proceedings - International Conference English Language and Literature Studies: Structures across Cultures, Volume I (eds K. Rasulić, I. Trbojević), Belgrade: Faculty of Philology, pp. 615-629.

Rasulić, K. i I. Trbojević /prir./ (2004). Katedra za anglistiku: 75 godina rada. Beograd: Filološki fakultet.

Rasulić, K. i I. Trbojević (2007). Povratak u budućnost: reformisani studijski program Katedre za anglistiku Filološkog fakulteta u Beogradu. U: Zbornik radova sa Interkatedarske konferencije povodom 35 godina postojanja Filozofskog fakulteta u Nišu (ur. Lopičić, V.i B.Mišić-Ilić), Niš: Filozofski fakultet, str. 407-422

Trbojević, I., Rasulić, K. and A.Jovanović (to appear in 2010) A Bridge Through Bologna:

the revised programme of academic studies at the Department of English at the Faculty of Philology in Belgrade within the European academic space. Paper presented at the Conference to mark the 50th Anniversary of the English Department at 'Blaže Koneski' Faculty of Philology, Skopje, Macedonia. September 2008.

Accepted for publication on 1 October 2010.

Ивана Трбојевић Милошевић

УЧЕЊЕ КРОЗ КОНТРАСТИРАҢЕ: СТУДЕНТСКИ ПРОЈЕКТИ НА КАТЕДРИ ЗА ЕНГЛЕСКИ ЈЕЗИК ФИЛОЛОШКОГ ФАКУЛТЕТА У БЕОГРАДУ

\section{Сажетак}

Генерација студената уписана школске 2006/2007 године је прва која је студирала по реформисаном програму Катедре за енглески језик и књижевност. Ова генерација је завршила студије у јуну 2010. Године, а истовремено је и прва генерација студената на курсу Контрастивна лингвистика са Уводом у корпусну лингвистику која није писала традиционалне семинарске радове, већ је учествовала у тимском раду на мини-пројектима у оквиру којих су тимови студената истраживали одређе- 
Ivana Trbojević Milošević, Learning through contrasting: students' projects ...

не лингвистичке теме ослањајући се на методолошке принципе контрастивне и корпусне лингвистике. У овом раду су презентовани принципи на којима се базирала одлука о уношењу овакве промене у наставни програм, циљеви рада на пројектима, имплементација тих циљева, као и резултати студентских истраживачких напора.

Кључне речи: Болоњска декларација, контрастивна лингвистика, корпусна лингвистика, реформисани програм, студентски мини-пројекти 
